\title{
'If Those Old Women Catch You, You're Going To Cop It': Night Patrols, Indigenous Women, and Place Based Sovereignty in Outback Australia
}

\author{
Harry Blagg \\ University of Western Australia \\ Thalia Anthony \\ University of Technology Sydney
}

\begin{abstract}
Night Patrols ('patrols') are a uniquely Indigenous Australian form of community selfpolicing. Patrols do not fit neatly into established paradigms of 'policing' emanating from the Global North. They are not part of the apparatus of the state police, nor do they offer commodified private security services and, unlike mainstream police, they cannot legitimately call on a reservoir of coercive powers to ensure compliance. In this article we sketch out what we describe as the 'contested space' of Indigenous self-policing, as represented by patrols, through a postcolonial lens, paying particular attention to the role of Indigenous women's agency in creating, nurturing and sustaining night patrol work within an Indigenous ethics of care and notions of wellbeing. Drawing on international critical postcolonial scholarship we tease out the links between patrol work and broader expressions of sovereign power embedded in Indigenous law. Our key contention is that there are learnings from the Australian experience for other postcolonies, where there are kindred debates regarding the balance between Indigenous and colonial systems of justice and policing. We highlight the experience of patrols in the Northern Territory (NT) where the policing of Indigenous space and place have become a key priority for the Australian Government after a major focus on issues of child abuse and family violence.
\end{abstract}

\section{Key Words}

Indigenous, Policing, Postcolonialism, Night Patrols, Northern Territory Intervention

\section{Introduction}

Night Patrols ('patrols') are a uniquely Indigenous Australian form of community selfpolicing. Established in the Northern Territory sometime in the $1980 \mathrm{~s}$, to combat alcohol related violence on remote communities, and operating without formal policing powers, or policy endorsement, they have come to occupy a pivotal position within current government funded and initiated remote community safety partnerships in recent years. Patrols do not fit neatly into established paradigms of 'policing' emanating from the Global North. They are not part of the apparatus of the state police, nor do they offer commodified private security services. Unlike mainstream police they cannot legitimately call on a reservoir of coercive powers to ensure compliance; and they have generally managed to avoid the kinds of vigilantism or coercive communitarianism, which have plagued popular or citizen mobilisation in other post-colonies and elsewhere. 


\section{Night Patrols, Indigenous Women, and Place Based Sovereignty: Blagg and Anthony}

In this article we sketch out what we describe as the 'contested space' of Indigenous self-policing, as represented by patrols, through a postcolonial lens, paying particular attention to a crucial feature of their work (though one often neglected in the policy literature), the role of Indigenous women's agency in creating, nurturing and sustaining night patrol work within an Indigenous ethics of care and notions of wellbeing. Drawing on international critical postcolonial scholarship we tease out the links between patrol work and broader expressions of sovereign power embedded in Indigenous law. Our key contention is that there are learnings from the Australian experience for other postcolonies, where there are kindred debates regarding the balance between Indigenous and colonial systems of justice and policing (see Kelley, 2000).

The balance between Indigenous and colonial systems of justice is nonetheless tested where the postcolonial state seeks to appropriate Indigenous strategies in order to assert a state agenda. We rely on the idea of the postcolonial state to explore how practices of the state resemble and affirm colonial techniques and discourses in the aftermath of colonialism. We highlight the experience of patrols in the Northern Territory (NT) where state policing of Indigenous space and place have become a key priority for the Australian Government after a major focus on issues of child abuse and family violence (Anthony and Blagg, 2012). While the increased resources for patrols, brought about by new government funding, has been generally welcomed, it has come with strings attached for communities who are being forced to surrender local autonomy, or, what we prefer to call 'place-based sovereignty'. For patrols, therefore, this new found favour, after years of being largely ignored by white government, is a double-edged sword.

Despite government attempts to focus the work of patrols on crime control and social regulation, patrol work envisaged by Indigenous communities cuts across the divisions created by white governance structures. It blurs cherished boundaries between welfare on the one hand (often viewed as a feminine domain) and social regulation on the other (a traditionally masculine domain). The success of patrols, from an Indigenous perspective, lies precisely in the fact that they transgress such divisions and are able to create a mix of 'place-based' approaches to local problems that work from within an Indigenous worldview. They also demonstrate that Indigenous communities can do better than simply reproducing those forms of policing and governance bestowed by colonial power, and western structures and processes are not the inevitable goal of 'development'.

Instead, patrols invite an exploration of what we shall call, after South American scholar Walter Mignolo (2011), opportunities for 'decoloniality', or the refinement of 'decolonial knowledge'. They demonstrate that Indigenous communities can produce ideas and strategies rather than simply consume those imposed from above by colonial power. The idea that the Global South can be a site from which to enunciate alternative epistemology, rather than simply an object of northern curiosity, underpins the work of South African anthropologists Jean and John Comaroff (2014), Australian sociologist Raewyn Connell (2007), and their counterparts in South America (see de Sousa Santos 
2008; Mignolo 2011). They criticise researchers from the Global North for tending to operate from within a set of culturally bound domain assumptions that position the Global South as a fractured site of under-development and backwardness - to be rendered knowable and, ultimately, redeemable though western methods and western intervention. From this elevated position of privilege researchers are able to look down on the 'third world' simply as a repository of 'unprocessed data' as well as unprocessed raw materials:

These other worlds ... are treated less as sources of refined knowledge than as reservoirs of raw fact: of the historical, natural, and ethnographic minutiae from which Euromodernity might fashion its testable theories and transcendent truths, its axioms and certitudes, its premises, postulates and principles. Just as it has capitalized on non-Western "raw materials" - materials at once human and physical, moral and medical, mineral and man-made, cultural and agricultural by ostensibly adding value and refinement (Comaroff and Comaroff 2014: 11).

Postcolonial critique essentially reverses the traditional process through which 'reality' is rendered knowable by researchers. It 'invert[s]' the 'order of things', in Comaroff and Comaroff's (2014: 12) expression, by questioning the impartiality, reliability and objectivity of the western researchers worldview (Smith 1999): that ubiquitous and omniscient white gaze (Hall 1981; Smith 1999). They also provide a critical stance of resistance in which Western practices are appropriated where they accommodate Indigenous practices and eschewed where they compromise Indigenous outcomes (see Agozino 2003 and Cohen 2007). Drawing on this approach, this article explores the experiences of patrols as an Indigenous domain that comingles with, as well as offsets, the state and its colonising core.

\section{Postcolonial Relationships}

Postcolonial critique starts out from the premise that relationships created by colonisation survive in the present and shape patterns of domination, subordination and resistance. Postcolonial theories provide a counterweight to Anglo-spheric narratives on law and justice that tend to ignore the role of colonialism in framing the contemporary global world (Gilroy 2011). Postcolonial relationships operate at a multiplicity of levels, creating intricate structures of sentiment, affect, attitude and feeling (Hook 2011; Said 1994,) and they continue to sustain a certain will to power on behalf of colonial agency, while giving voice to cultural alterity and its resistance to colonisation's ongoing project. It eschews vulgar Marxist notions of history as a series of stages supplanting preceding social systems. Postcolonial theories seek, instead, to rescue the colonised subject's society and validate subaltern voices drowned out by colonial discourses. The postcolonial framework has distinct relevance to Indigenous patterns of struggle, by validating resistance that does not seek to topple colonial power, but reconfigure relationships to create plural forms of sovereignty. It links in with new thinking regarding the benefits of 'inter-cultural' dialogue that attempts to 


\section{Night Patrols, Indigenous Women, and Place Based Sovereignty: Blagg and Anthony}

construct engagement spaces in-between cultures and respect a 'pluriverse' of epistemologies and worldviews (Escobar 2011). For criminologists such as ourselves, thinking within a decolonial space requires a degree of 'disciplinary disobedience' (Mignolo 2011), deliberately stepping outside the boundaries of a discipline which often uncritically defends various hegemonically sanctioned divisions, such as the normal and the pathological, as well as state (legitimate) and non-state (illegitimate) legal and punishment systems.

Indigenous women's agency, often neglected within the 'development' literature concerned with social and economic change (see Radcliffe 1999), takes on greater significance within a postcolonial framework. Women's patrols 'uncouple' or 'delink' the 'colonial matrix of power' (Mignolo 2011) embedded in the imagery of the 'patrol'. They depart from their mono-culturally authorised position as a form of surveillance by the state. Instead narratives of the practice of patrolling become a story of community strength and cohesion.

\section{Narratives of Empire, Narratives of Masculinity}

Policing, even community volunteer and 'special' policing, is still viewed as a quintessentially male activity (Reiner 2000) underpinned by narratives celebrating 'traditional' male values of authority, dominance and masculinity. Furthermore, policing in contemporary society does not simply reflect dominant cultural values, it constitutes a key site for the production of hegemonically dominant ideals of masculinity. Policing privileges the public streetscape over relationships in the private sphere. Within the Indigenous domain, women's patrols offer a different model of policing, based upon Indigenous notions of mutual reciprocity, consensus and inclusion (Blanchard and Lui 2001; Turner-Walker 2011). The fact that Indigenous women are highly represented in patrols as workers (and, indeed, clients) across Australia, raises two, interconnected questions: firstly, what can be learned about the role of women in shaping non-adversarial paradigms of community level intervention and policing that take us beyond heavily masculinised crime control discourse? Secondly, what can be learned about the role of Indigenous women's agency in sustaining and nurturing forms of Indigenous cultural practice that challenge 'colonial patriarchy' (Baldry \& Cunneen 2014), or what Aileen Moreton-Robinson (2007) terms 'patriarchal white sovereignty'?

Policing in Australia has traditionally represented a powerful tool of colonial subordination and control (Cunneen 2001; Finnane 1994). Colonial policing prepared the ground for the implantation of colonial law and sovereignty by 'dispersing' Aboriginal people and moving them off their traditional lands. 'Policing' offered a powerful means of projecting and communicating white sovereign power: a process Spivak (1996) refers to as 'worlding': where the colonised space is inscribed by the worldview, systems, laws and practices of the coloniser. What's more, British colonial policing tended to leave the winning-hearts-and-minds through 'community' policing primer at home; in the colony strangers policed strangers. So, as Hannah Arendt (1958) and Frantz Fanon (2004) adroitly observed, though the west practiced a degree of tolerance and democracy at home, oppressive and militaristic solutions, attitudes 
and values were allowed unrestrained license in what Marx (1985) called the "hot house' of the colony. Agozino (2003) regards the imposition of the rule of law as a form of 'organized violence', in which atrocities against Indigenous people are sanctioned in order to sustain the postcolonial order.

While the police and other white agencies attempt to 'world' Indigenous space as white space through police patrols (which inevitably ensure Indigenous over-representation in the white justice system), patrols conduct a form of 'counter-worlding' through the inscription of Indigenous meaning, values and laws as they patrol Indigenous 'place' as a concrete and localised entity, with a specific history: not strangers policing strangers but Indigenous people regulating their own place. This counter-worlding involves the performance of Indigenous sovereignty, reproducing the Aboriginal domain as a living and dynamic social and spiritual entity, rather than as a static fragment of the premodern world, or a 'basket-case' to be redeemed by white agency.

The patrols issue also intersects with other global debates on policing, besides those around colonial power and masculinity. Critical scholars suggest that traditional models of policing are being reconfigured under conditions of neo-liberalism, with a shrinking public sector and an expanding private domain (Bayley \& Shearing, 1996; Shearing \& Stenning 1997). As Lucia Zedner (2006: 269) argues:

It now appears increasingly possible that this model of the police may come to be seen as a historical blip in a more enduring schema of policing as an array of activities undertaken by multiple private and public agencies, and individual and communal endeavours.

The 'plural policing' turn, wherein the state sheds its monopoly on policing and tolerates a diverse mix of policing providers, does offer a lens through which to view the growth of investment in night patrols: reflecting a greater willingness amongst policy makers, non-state actors and others to think outside the 'box' where policing is concerned to consider other actors than the formal police. However, in outback Australia, the analysis needs to be situated within a postcolonial context where issues of colonial power over-determine such neo-liberal imaginaries. The growth in investment in patrols in the Northern Territory (NT) by government supplemented a massive increase in traditional state policing and in the role of government more broadly. Anthony (2010: 92) refers to this as a means of governing crime with the number of police stations in the NT increasing by over 50 per cent and a law and order investment of \$A130 million; and governing through the justification of crime with greater controls on Indigenous welfare expenditure, family arrangements, medical checks and the use of Aboriginal land. Here, state and non-state actors were encouraged to perform subaltern tasks within new regulatory assemblages (which included both NT police, Australian Federal Police, various police 'task forces' focused on child sexual abuse, multi-disciplinary teams, social workers, health workers and 


\section{Night Patrols, Indigenous Women, and Place Based Sovereignty: Blagg and Anthony}

new governance bureaucrats such as Government Business Managers, etc), rather than being invited to perform policing tasks independently. Government funding for patrols was not intended to increase self-determination but expand the capacity of government agencies to regulate communities (see Altman and Hinkson 2007).

The space/time of postcolonial conflict and contestation has its own particular rhythmic flow, conditioned by relationships of domination, subordination and resistance set in train by the colonial encounter that continue to exert enormous influence on the consciousness of the settler colonists and the Indigenous colonised, irrespective of dominant economic ideologies: for there are deep currents here, historical concatenations and flows that defy the closure techniques of western temporal periodization (Blagg 2008a, 2008b, 2012). These flows are encapsulated in Edward Said's (1994) notion of 'contrapuntal' time, conceived to escape the totalizing narratives of colonial discourse, where history is imagined as a series of more or less completed stages, moving ineluctably forwards through linear time. Contrapuntal themes, in contrast, are always unfinished, unsettling, repetitive and reprising. According to Said, contrapuntal themes 'travel across temporal, cultural and ideological barriers in unforeseen ways' (Said 2003: 24).

The space/time of postcolonial conflict in Australia has incubated a routinized 'state of exception', originating in the founding violence of the colonial encounter, when the control, displacement and dispossession of the Indigenous minority justified extreme, 'emergency' measures and, at the level of the collective unconscious, it instilled an existential dread of the Indigenous Other. This dread cohabits with other objects of anxiety and paranoia for the white mainstream exhibited in Australia's draconian measures to 'stop the boats' and the archipelago of offshore detention regimes it has spawned to 'process' asylum seekers. For Moreton-Robinson (2007) the twin 'threats' of Indigenous peoples and asylum seekers play on white anxieties about invasion and dispossession - they displace the founding experience of colonisation onto both internal and external threats to white national sovereignty (Moreton-Robinson 2007).

Our article draws on a number of field research projects undertaken by the authors in Central Australia (a vast semi-desert area surrounding Alice Springs with fluctuating populations of about 1,000 people) between $2007-11$, the most recent being an investigation of policing related issues following an Australian Commonwealth Government intervention which significantly increased the quantum and density of white law and order on remote communities. Experience suggests that extending the disciplinary and criminalisation powers of the settler state deeper into the Indigenous domain does not necessarily reduce social problems in these communities or ensures the maintenance of social order; instead, as Chris Cunneen (2011) argues, it has a tendency to intensify levels of disadvantage and undermine social order. Before analysing these issues in detail a brief description of night patrols and how they work.

What are they and how do they work?

Night Patrols (patrols) represent the longest running form of Indigenous community 'owned' crime prevention initiative in the NT (Curtis 1993; Mosey 1994; Ryan 2001). 
They provide assistance for target groups in need or at risk and operate both mobile and foot patrols, depending on context. Although their functions vary, they converge on safe transportation, dispute resolution, prevention of family violence, homelessness and substance misuse (including petrol sniffing), and diversion from contact with the criminal justice system (Blagg 2008a). They transport people to community and government facilities, where available, such as sobering-up shelters, safe houses, women's refuges, men's places, clinics, hostels, 'family healing' and justice groups, and they liaise with case workers and the police (Memmott \& Fantin 2001; Pilkington 2009; Ryan 2001;). In some states (Western Australia for example) they are involved in truancy patrols and, in partnership with breakfast programs, ensure children are on time for school (Blagg 2006).

An early review of patrols across Australia (Blagg \& Valuri 2004) found there were around 150 patrol schemes Australia wide and they functioned in urban as well as rural and remote settings. They varied in size, with some urban patrols being able to mount wide-ranging services in partnership with government and non-government agencies, while others may involve a few community members intervening with drinkers, settling disputes or checking on children to ensure they are safe.

In the absence of consistent government investment, community based crime prevention initiatives in the NT have traditionally relied heavily on local cultural knowledge and localized resources in the absence of consistent government support. Patrols have played an important, though inconsistent and ad hoc, role in enabling Indigenous communities to restrict the flow of alcohol and take the heat out of potentially combustible situations. The landscape in the NT has changed markedly since 2007, when there was a 'surge' in police numbers on remote Indigenous communities.

\section{The Intervention and the Police Surge}

The policing surge complemented a series of new regulatory policies and practices (collectively known as 'the Intervention'), intended to tackle what was believed to be endemic child abuse and family violence in Indigenous communities in the NT. In May 2006 claims of endemic family violence and the sexual abuse of children in remote NT communities attracted the attention of the conservative Australian Government and led to the initial mobilisation of Federal police to the Northern Territory in mid-2006. A year later an official inquiry (Wild and Anderson 2007) was released which, even though it recommended community capacity building as a solution and expressed some scepticism about official claims regarding the scale of abuse, was deployed as a casus belli by the Australian Government, on the basis that a crime epidemic in Indigenous communities had reached crisis levels. The implication was that the situation required broad-sweeping legislative measures to address Indigenous dysfunction and announced that it would be taking control of 73 Indigenous communities in the Northern Territory. The Australian Government introduced a 


\section{Night Patrols, Indigenous Women, and Place Based Sovereignty: Blagg and Anthony}

number of legislative and non-legislative measures to increase law enforcement and government regulation in Indigenous communities. The key legislative measure was the Northern Territory National Emergency Response Act 2007 (Cth), which was directed at protecting Indigenous children from abuse.

Empirical research (Anthony and Blagg 2012) could find no discernible increase in prosecutions for family violence, or in notifications of child abuse to social services, post-Intervention, but did uncover a massive increase in the rate of prosecutions for minor driving-related offending across the NT. The Northern Territory prison rate has increased faster than any other state or territory since the Intervention, with a 52 per cent increase between 2006 and 2012: rising from to 542 to 826 prisoners per 100,000 adult population - becoming the highest imprisonment rate in Australia (Australian Bureau of Statistics (ABS) 2006: 14, 2012: 27). Aggregate prison numbers have increased by 78 per cent: from 792 in 2006 to 1,411 in 2012 (ABS 2006: 37). The Indigenous population constitutes 86 per cent of the total prison population of the NT - an increase from 82 per cent in 2006 (ABS 2006: 5, ABS: 2013). This was the highest Indigenous prison population of any Australian jurisdiction. Given that the Intervention was legitimated on the basis of Indigenous women's safety from abuse it is particularly disturbing, although not surprising, to note the significant increase in the number of Indigenous women being incarcerated in the NT post-Intervention. In the NT, 93 per cent of female prisoners are Indigenous, according to NT 2013 Annual Corrections Report (NT Department of Correctional Services 2014: 15). The report finds a 31 per cent increase in the number of sentenced Indigenous female receptions and a 30 per cent increase in the number of un-sentenced Indigenous female receptions into adult correctional centres during 2012-13 compared with the previous year (NT Department of Correctional Services 2014: 21). This matches the longer-term increases of 33 per cent in NT female imprisonment between 2003 and 2013 producing the highest female imprisonment rate in Australia of 130 prisoners per 100,000 (see Diagram 1 and ABS 2013). 


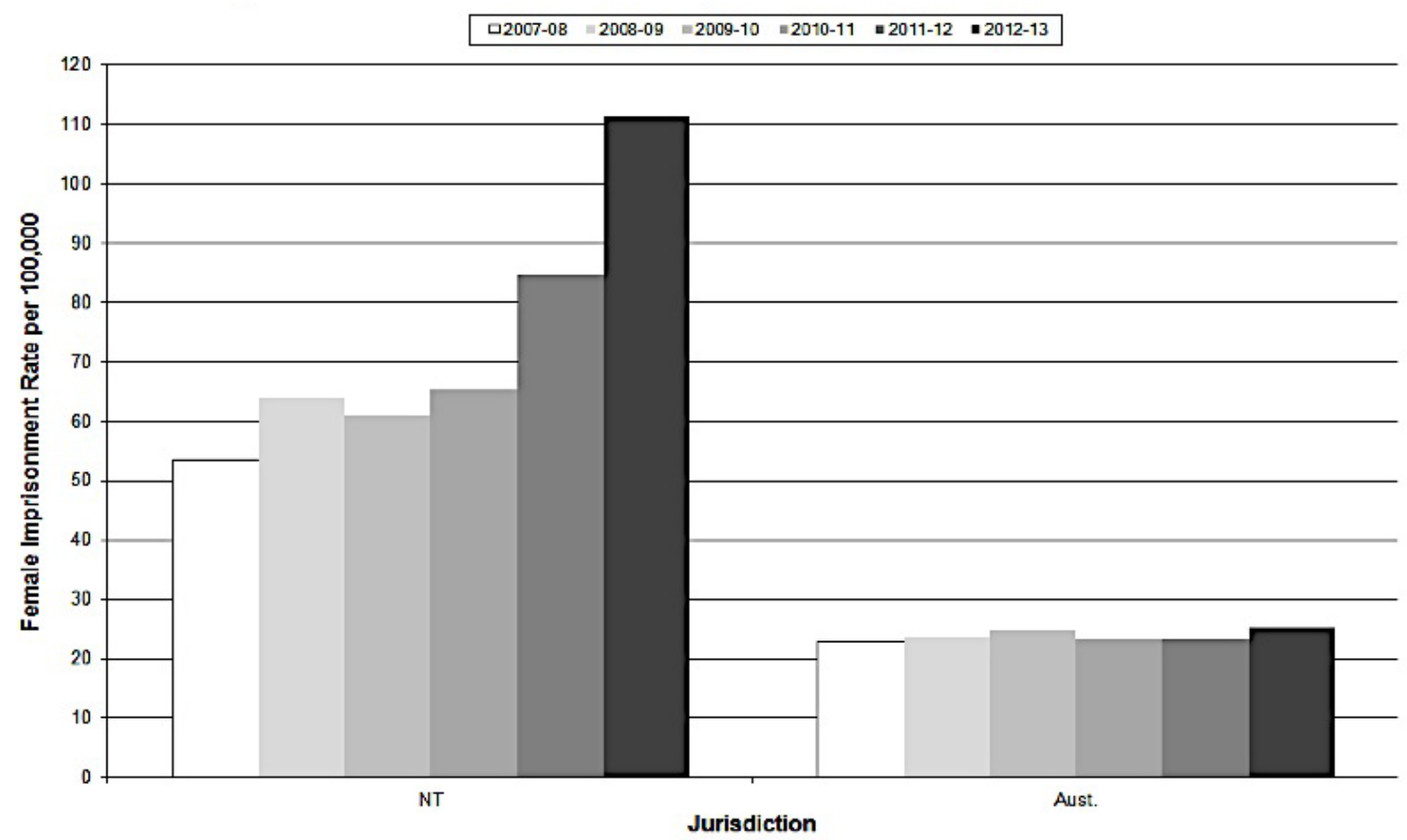

Diagram 1. Comparison of imprisonment rates in Northern Territory and Australia-wide, 2007/8-2012/13.

Source: Northern Territory Department of Correctional Services, Annual Statistics 2012 - 2013 (2014: 7).

This led us to conclude, following Jonathan Simon (2007), that the increased criminalisation of Indigenous people constituted an attempt to 'govern through crime' in the NT (Anthony 2010; Anthony \& Blagg 2013), with the settler state seeking to normalise the 'outback', assimilate its space into the Australian mainstream, and eradicate Indigenous difference (Anthony and Blagg 2012). This aim took precedence over the safety of Indigenous women, unless prison has become the new site for 'saving' Indigenous women.

\section{New Night Patrols: Contested Definitions}

The significant increase in police resources from 2007 was complemented by the creation of 50 'new' Night Patrols - bringing the full complement to over 80 with over 350 paid positions. Given the high attrition rate for patrols in the NT, and a tendency for patrolling to be a cyclical phenomenon - its rhythms influenced by a mix of financial, cultural and social factors (Higgens and Associates 1999; Ryan 2001) it is difficult to assert with confidence how many of the 'new' schemes were in fact new. A number of them were clearly built upon the foundations of earlier schemes. The patrols, with a few exceptions, were to be administered by NT 'Shire Councils', according to Federal operational guidelines (ANAO 2011: 89). The effect was the immediate disempowering of local communities that tended to administer patrols through their own local councils. 


\section{Night Patrols, Indigenous Women, and Place Based Sovereignty: Blagg and Anthony}

There were a number of competing definitions in play regarding the role of the patrols as part of the Intervention. The NT police have tended to see patrols as the 'eyes and ears' of the police on remote communities, playing an essentially subaltern role in local policing strategies - a categorisation rejected by patrols themselves who see their work as radically different from mainstream policing. Indeed, many believed that their core task was to act as a buffer between the community and the police (Blagg and Valuri 2001). Patrols often emerged because of the unwillingness of police to become involved in problems in Aboriginal communities - not surprisingly given the extent to which colonial policing was focused upon maintaining the divide between coloniser and colonised. Julalikari Patrol, one of the longest running patrols in Tennant Creek (central NT), emerged because of Aboriginal people's 'dissatisfaction with policing in their communities' (Langton, 1991: 439) and because no government security agencies were intervening to halt 'the escalating violence, trauma and deaths in the towncamps' (Curtis, 1993: 74). Curtis (1993: 77) firmly refutes suggestion (largely made by the police) that Julalikari existed to 'assist the police remove intoxicated people from the streets' instead, he argues the purpose of the Patrol was to resolve, or head off, disputes before they became un-manageable. More recently, patrols have become features of a crime prevention and community safety imaginary, where the activities of patrols are viewed as adjunct to government strategies designed to reduce levels of social disorder in communities. Patrols would agree that they have an important role to play in this area, but there are some fundamental areas of disagreement between patrols and government about how this can best be achieved. These conflicting definitions of the roles and purposes of patrols has become a site of contestation between Indigenous communities and white structures of governance.

\section{What Makes for a Good Service?}

Although the evidence is limited, extant commentary suggests that patrols are most effective when under local control and responsive to community needs. They should enjoy strong cultural legitimacy and be staffed by 'cultural insiders' (Turner-Walker, 2011:7) who, because of their standing, and knowledge of Indigenous protocols, can mediate disputes. There is also an important role for 'sympathetic outsiders' (Blagg 2008a) who can negotiate non-Indigenous structures and processes. Patrols should be integrated into a diverse range of local Indigenous and non-Indigenous mechanisms rather than just 'stand-alone' initiatives and, crucially, they must be respectful of gender, language and clan affiliation in their working practices (Barcham 2010: 531 Blagg 2006; Charles Darwin University 2009; Commonwealth of Australia 2009: 4; Cunneen 2001; Curtis 1993; Higgens and Associates 1997; Memmott and Fantin 2001; Ryan 2001; ).

A good example of patrols working in an integrated and holistic fashion is provided by patrols on Lajamanu and Yuendumu (remote communities of Warlpiri people in Central Australia) with a proven track record of creating and sustaining a diversity of community owned initiatives, including safe houses, law and order committees, healing centres and crime prevention committees (for a review of law and justice strategies involving Lajamanu and Yuendumu, see Ryan 2001, 2005; Ryan and Antoun 
2001). Yuendumu has both men's and women's patrols. The latter, under the indomitable leadership of Peggy Nampijimpa Brown, is the longest running women's night patrol in Australia. However, the women patrollers recognised that no agencies was effectively dealing with the issue of petrol sniffing among young people on the community, which was having a devastating impact. The Mt Theo Youth Diversionary Program, established by Traditional Owners Peggy Nampijimpa Brown, Barney Japangardi Brown and Johnny Japangardi Miller, to stop petrol sniffing (with the support of another Aboriginal organisation the Central Australian Youth Link-Up Service (CAYLUS) run by Tangentyere Council in Alice Springs) and is acknowledged to be a gold standard program (Stojanovski 2010). Mt Theo, with support from CAYLUS, has eradicated petrol sniffing on Warlpiri land, and has developed a sophisticated, holistic program involving education, employment and cultural engagement to offer meaningful and safe programs for youths on communities in Central Australia: an approach endorsed by government announcements post-NT Intervention (see FaHCSIA 2009). The men's and women's patrols at Mt Theo complemented other community owned initiatives, such as a Men's Shelter and the Women's Refuge.

The women's patrol on Yuendumu is respected, even by unruly young people, because the women are senior Elders on the community. They are the aunties and mothers of the young people they patrol and, on occasion chastise, or 'growl'. As the coordinator of the patrol told the Australian Broadcasting Corporation news:

[E]verybody knows they're there so if you're going to go and smash cars up, you just never know when Night Patrol's going to come around the corner and you know that if those old women catch you, you're going to cop it (Lee 2008).

The women's patrol has, according to some commentators, not always received the respect it deserves from the mainstream community. For example, Lloyd and Rogers (1993) critique an article on the Yuendumu women in the Weekend Australian (7/8 March 1992) that refers to these respected, senior law women as the 'Granny Vice Squad'. They remark:

The night patrols have been instrumental in reducing the level of assaults in the town camps and, at Yuendumu, there has been a noticeable drop in a range of assaults and offences. The Yuendumu women's night patrol has received some media coverage which has described the women as the 'Granny Vice Patrol' thus belittling their authority and law, which is the basis of their success in maintaining law and order at Yuendumu...This is another example of the way in which Aboriginal women are excluded from any pronouncements of law and culture (Lloyd and Rogers 1993: 162). 


\section{Night Patrols, Indigenous Women, and Place Based Sovereignty: Blagg and Anthony}

\section{Ties that Bind: Aboriginal Law}

As Lloyd and Rogers observe, initiatives generated by NT Indigenous communities, such as patrols, are anchored in Indigenous law, meaning that their authority to intervene in local issues is derived from cultural authority (see also Blagg 2006: 3-4; NT Law Reform Committee 2003). Notwithstanding the increased presence of government agencies and police in NT communities since 2006, Indigenous cultural obligations continue to have significant influence on Indigenous life in remote areas. Indigenous people pursue justice through many different community avenues and not only through the police (Pilkington 2009: 7). Aboriginal law binds people together and creates an intricate patchwork of relationships, obligations and ties. Patrols operate according to the precepts of Aboriginal law, respecting 'avoidance' practices and the distinct rules governing relationships between different moiety or 'skin name' groups. ${ }^{i}$ Indeed, as we argue later, patrols do not simply operate within limits set down by Aboriginal law, they actively exercise and reproduce the law when they patrol communities, as many of the women are respected Law Women, responsible for important ceremonies, songs, dances, places and stories within the Jakurpa (usually translated as 'dreamings' by non-Indigenous people). It is possible to find them during the day painting outside the Warlukurlangu arts centre, or participating in the Yuendumu Mediation and Justice Committee which attempts to bring Indigenous notions of dispute resolution into the Magistrate's Court. These senior women help to knit together the community through the practice of what Aboriginal people in Central Australia call Kanyini, which translates best as a form of mutual care that engenders respect for the spiritual basis of Indigenous life. Respect for gender difference is reflected in the number of distinct men and women's patrols in the NT. Men and women have their own forms of law 'business', dreamings and ceremonial spaces. This is reflected in the ways men and women's patrols divide their work on communities, to avoid prohibited forms of contact, and particular prohibited places.

It is important to acknowledge patrolling is a gendered activity in Indigenous communities. Blagg and Valuri (2001) found that around 50 per cent of patrollers in Australia are women and that women represent roughly half of the clients, and often have very specific views about the nature of the work, tending to have a stronger 'ethic of care', be less authoritarian and more welfare orientated than male patrollers (Blagg and Valuri 2001; TurnerWalker 2011). Jennifer Turner-Walker (2011) argues that men's patrols have a tendency to copy the masculine culture of state police in the way they approach patrol work, focusing on authority, whereas women's patrols do not need to project an authoritarian persona. For men, and many Indigenous men included, performances of masculine authority are the default form of 'doing policing'. Women's patrols show how a critical mass of women's agency in policing roles can transcend some of the negative macho elements in policing culture.

\section{Government Interest in Patrols}

Patrols in the NT, however, had a high failure rate and were plagued by poor 'establishment practices' and governance systems (Ryan 2001). They were vulnerable to being poorly managed and/or the property of a particular clan or faction (Ryan 2005; Ryan and Antoun 2001), and lacked financial stability and sustainability (Mosey 
1994; Higgens and Associates 1997). Men's patrols in particular were often undermined by jealousy and aggressive 'demand sharing' over the culturally prized NP vehicle - many men were unable to refuse relatives demands to use the vehicle to go hunting or even go to town to buy grog. However, Indigenous agency in the NT had gone a long way to resolving these troubles. In Central Australia, the Tangentyere Aboriginal Council in Alice Springs established Remote Area Night Patrol in the early 2000 s, a training and support agency that worked with community patrols and provided financial and other forms of support. Unfortunately, this task was taken over by the new local government Shires, who had little understanding of, or interest in, patrol issues and for who patrols were never 'core business' (Turner-Walker 2011).

Patrols do need support from government to buy vehicles, uniforms, radios, and to pay patrollers and run a base on the community. The Australian Commonwealth Government has provided these things and has recently pledged to maintain funding for them as part of its Stronger Futures policy (Australian Government 2014). For the first time nearly every remote community and town in the NT has an Indigenous NP. However, greater security of Australian Government funding has come at a price: an increasingly more restrictive regulatory environment that, whilst seeking to protect the safety of patrollers and ensure some degree of consistency in role and remuneration, has reduced local control and responsiveness. They have been increasingly co-opted as junior partners in new security assemblages in NT towns and remote communities.

Government agencies involved in funding and administering patrols, such as the Australian Federal Attorney General's Department, who, due to the Intervention, had become key players in community justice and safety strategies in the NT, tend to view patrols through a western crime prevention lens. They acknowledge that local community justice mechanisms have been successful in responding to Indigenous needs and improving safety, and saw them as a vehicle for helping community members "who may be at risk of either causing harm or becoming a victim of harm" (ANAO 2011: 27). Accordingly, funding for night patrols has been geared towards relocating at-risk people to safe places and services, and supporting police work (Attorney-General 2013). The Australian Government's (2012: 2) Stronger Futures strategy in the NT places importance on patrols within a 'community safety' paradigm:

Community night patrols are a key element of the Community Safety and Justice measure, which supports continued improvements in community safety for remote Aboriginal communities in the Northern Territory. This measure also includes policing and supplementary legal assistance services. These initiatives are improving community safety for Aboriginal people living in remote areas, by enforcing alcohol restrictions, maintaining law and order, and working with local people to keep their communities safe. 


\section{Night Patrols, Indigenous Women, and Place Based Sovereignty: Blagg and Anthony}

In mandating the roles of night patrols this way, the government has sharpened the focus of their work on crime and violence reduction, to the detriment, some suggest, of their other community functions that may not fall within the arena of crime prevention per se but which are, nonetheless, crucial for maintaining their legitimacy and credibility with communities. Contrast the Stronger Futures statement above to the description offered by Walker and Forrester who describe patrols as creating a holistic service connecting people with a whole range of services.

Night Patrols perform a huge range of functions, according to the needs of their communities and the resources they have available. They act as a nexus to connect people and services such as clinics, courts, Police, community government councils, and family. They mediate disputes, remove people from danger, keep the peace at events such as sports carnivals, are consulted by agencies such as courts for input into sentencing, and play a crucial role in the development of community justice groups (Walker \& Forrester 2002: 2).

These functions required patrols to travel off-community and be on hand when countrymen became lost in the bush or broke down on the highway. If not able to fulfil these social functions their legitimacy may be sacrificed in a way that undermines the patrols lawful authority to intervene and compromise its capacity to deliver safety outcomes in the longer term. Government, rather than communities, increasingly establishes the rules by which patrols operate, and governments have clearly attempted to define 'core business' in a way that restricts patrols to activities that can be measured in directly 'crime prevention' terms. On one occasion on the Yuendumu community we witnessed a situation where a young man was reported lost in the bush. The men's night patrol was prevented from searching for him because it was 'off community' and the manager said the patrol was not funded to provide this service. The patrol leader, a local Elder in a kin relationship with the young man, lost the respect of the boy's family and, with it, much of his authority. This, he said, would undermine his capacity to intervene with drinkers and troublemakers when violence erupted in the community, as this capacity was dependent on his place in a web of reciprocal duties and responsibilities.

Research asserts the importance of strengthening Indigenous culture and reintegrating offenders through community-based programs (Gaykamangu 2012; Loy 2010; Wild \& Anderson 2007: 175-92). Communities regard formal justice processes as only one aspect of safety work, which equally relies on avenues such as Indigenous ceremony, Aboriginal conflict resolution strategies involving Elders and family (Blagg \& Valuri 2004; Memmott et al 2001; Pilkington 2009: 157- 9; Walker \& Forrester 2002). In a 2011 survey of local Indigenous people in 16 NT communities, three-quarters reported that patrols made a difference to community safety (Putt \& FaHCSIA 2011). Another study on perceptions of service providers found that 48 per cent believed that night patrols and community police were 'the most important community safety initiatives' (Willis 2010: 38). 
Qualitative evidence, by academics, government bodies and law reform commissions, that patrols play an important role in harm reduction and improved community governance are based on measurements such as whether they are embraced by the community, collaborate with other community services and have positive outcomes from their encounters (Beacroft et al 2011: 4; Blagg 2006: 3-4, 46). Observations of two remote communities in Western Australia suggest that patrols substantially reduced the number of admissions to police lock-ups (Blagg 2006: 24; Blagg \& Valuri 2003: 20-1). There is also evidence of reduced juvenile crime rates, alcohol-related crime and protective custody rates (Cunneen 2001: 9, 41-2). The Tangentyere Council Patrollers (2007: 3) in central Australia found that of the 9,396 encounters, 8.7\% involved violence and the majority of these were diffused without police involvement. In two-thirds of all encounters, the community member was transported home or to a safe place. Monitoring data of central Australian patrols found that they play an important role in strengthening Indigenous cultural authority (Turner-Walker 2011). Equally, there is a perception in communities that patrols enhance cultural understanding between the Indigenous and non-Indigenous domains.

Aboriginal communities and government agencies may share common objectives (crime reduction, increased community safety, reduced incarceration) but may have radically different understandings of the processes necessary to achieve them. When developing initiatives funding bodies and agencies tend to focus primarily on issues related to budgets, reporting and management, administration and so on, and give secondary importance on the need to ensure projects are culturally embedded. Peter Ryan (2005) argued that much of the policy debate about patrols has taken place around issues not of central importance to Aboriginal people and was premised on non-Indigenous 'social, cultural and political structures'. He maintained:

The debate about night patrols is yet to properly focus on important Indigenous concepts and requirements that may be necessary for the successful implementation of night patrols (Ryan 2005: 1).

Ryan demonstrates this through a discussion of the principles underpinning the Kurduju Crime Prevention Committee, a body created by Aboriginal women from the communities of Ali-Curung, Lajamanu and Yuendumu. These women, as we noted above, had founded their own patrols and safe houses as well as the successful Mount Theo petrol sniffing diversionary program. They did so by working through traditional law and cultural processes and ensuring that communities had a strong voice in how the processes should operate. Ryan (2005: 3) notes the importance of 'work-shopping' issues over a period of time, to "identifying community capacity, and the likely strengths and impediments that may affect the process. These can vary from community to community". 


\section{Night Patrols, Indigenous Women, and Place Based Sovereignty: Blagg and Anthony}

Has Australian Government investment, then, come at the expense of local autonomy and community-ownership? Patrol training is now developed by 'cultural outsiders' based on pre-existing modules from other government courses, rather than sensitive to the specialised roles and skills of patrollers. The training replaces the accredited courses developed by Indigenous organisations within communities (Turner-Walker 2011: 56, 138). Due to the new government guidelines, patrols can only travel within immediate community borders, which, as we demonstrated earlier, has stopped them assisting those in drinking camps by returning them to safe places, such as a soberingup shelter (Pilkington 2009: 161, 188). There is a conflict between patrollers' characterisation of their duty as extending to those on outer community camps, and funding agencies' characterisation as only assisting those in community. Operation and employment models also preclude patrols from travelling to events, such as sports weekends where disputes can arise, assisting with court appearances or looking for lost people and broken down vehicles (Turner-Walker 2011: 136-7). Hours of operation of patrols and the terms and conditions of patrol employment are now prescribed centrally removing patrollers' ability to respond rapidly and strategically to community conditions (Ibid: 137).

Taking the 'crime prevention' focus to its logical conclusion raises the question: do patrols need to be community 'owned' initiatives, 'mandated' by Aboriginal law if their tasks are restricted to simply transporting inebriated people and acting as police scouts on communities? Turner-Walker (2011) observed that this logic is having an impact on the working style and composition of patrols. Elders feel their cultural authority is neither respected or valued by the new managers on communities and are drifting away from involvement, while non-Indigenous people, better able to negotiate white bureaucracy, are taking up positions on patrols.

In addition, funding is now largely channelled through local governments: a fact that may constrain local approaches to community safety. Also, the broader context in which night patrols operate has changed significantly due to the increased policing presence in many communities and the substantial expansion in social services (such as child protection, health and youth services). Relationships between these services and Indigenous people can be positive and complementary - drug and alcohol services staff, youth workers and medical services staff we spoke to respected the work of patrols and saw them as essential partners of any harm minimisation strategies on communities and an important means of diverting people from the criminal justice system (see also ANAO 2011: 83, 93-8; Beacroft et al 2011: 3-4; Blagg 2006: 2-3; Blagg \& Valuri 2003: 59; Cunneen 2001: 41). We spoke to some shire officials and police, however, who were sceptical about the value of patrols and deliberately sought to bypass them when developing strategies around liquor restrictions. There were also concerns that there was no clear demarcation of the roles and responsibilities between patrols and other agencies, particularly the police, in protocols established for 'working together' (ACG 2010: 71). There is a view among Indigenous community members, for example, that "while the night patrol support the work of the police, the police often do not reciprocate" and there is a lack of understanding between community groups and government agencies (Pilkington 2009: 112). 


\section{Concluding Comments}

In this article we have discussed the role of Night Patrols in the outback Northern Territory. We have argued that it is necessary to place them within a history of postcolonial conflict and attempts by Indigenous people to police themselves in accordance with Indigenous law and culture. Night Patrols demonstrate how Indigenous groups can operate autonomously and through the authority of their community. It juxtaposes and challenges the imagery of legitimate authority that attaches to formal postcolonial policing. Unlike postcolonial policing, night patrols operate to strengthen rather than subordinate Indigenous communities. They assert Indigenous rather than settler law and do much more than fill in the gaps where there is a white policing vacuum, or to be ancillary to the state police. Rather than being incorporated into postcolonial relations or coopted by the mainstream system, despite its attempts since the 2007 Northern Territory Intervention, patrols play a role in recuperating Indigenous law and authority, and expressing Indigenous sovereignty.

We have also noted the significant role played by Indigenous women in patrolling. The role of women in these patrols provides valuable lessons for other postcolonial contexts. Such involvement demonstrates that Indigenous women in the NT, far from being the docile, passive victims of Indigenous male violence (an imaginary that flourished in the lead-up to the 2007 Intervention and legitimated the punitive turn) are actively engaged in running their communities and are bearers of sovereign power. This does not negate the fact that Indigenous women in the NT are amongst the most victimised section of Australian society. Rather it shifts the focus of attention away from solutions based solely on top down strategies, such as more arrest and incarceration of Indigenous men (which, ineluctably leads to more incarceration of Indigenous women) and points, instead, to building upon women's capacities and developing partnerships with place-based Indigenous structures. Currently, it seems, prison is the only consistent 'refuge' the white legal system can offer Indigenous women. Furthermore, women's patrols have created a form of community policing based upon an ethics of care, rather than of surveillance and punishment, and illustrate what can be achieved when a critical mass of women's agency influences the direction of policing and safeguards community well-being.

\section{References}

ACG (Allen Consulting Group) (2010) Independent Review of Policing in Remote Indigenous Communities in the Northern Territory: policing further into remote communities, Report to the Australian Government and the Northern Territory Government, Melbourne.

Agozino, B (2003) Counter-Colonial Criminology: A Critique of Imperialist Reason. London; Sterling, Virginia: Pluto Press. 


\section{Night Patrols, Indigenous Women, and Place Based Sovereignty: Blagg and Anthony}

Altman J and Hinkson M (Eds.) (2007) Coercive Reconciliation: Stabilise, Normalise, Exit Aboriginal Australia. Melbourne: Arena Publications.

ANAO (Australian National Audit Office) (2011) Northern Territory Night Patrols, Auditor-General's Performance Report No 32 2010-11, Attorney-General's Department, $\quad$ Canberra: http://www.anao.gov.au/ /media/Uploads/Documents/2010 11 report 32.pdf.

Anthony T (2010) 'Governing Crime in the Intervention', Law in Context, 27(2): 90.

Anthony T and Blagg H (2012) Addressing the Crime Problem of the Northern Territory Intervention: Alternate Paths to Regulating Minor Driving Offences in Remote Indigenous Communities, Report to the Criminology Research Council, Grant: CRC 38/09-10, Canberra.

Anthony T and Blagg H (2013) 'STOP in the Name of Who's Law? Driving and the Regulation of Contested Space in Central Australia' Social and Legal Studies, 22(1): 43.

Arendt H (1958) The Origins of Totalitarianism. Meridian Books: New York.

Attorney-General's Department (2010) Night Patrol Services in the Northern Territory: Operational Framework. Canberra: Attorney-General's Department.

Attorney-General's Department (2013) 'Community Night Patrols in the Northern Territory'. Canberra: Attorney General's Department.

Australian Bureau of Statistics (ABS) $(2006,2009,2012,2013)$ Prisoners in Australia, 2011. Cat. No. 4517.0, Canberra.

Australian Government/Closing the Gap (2012) Stronger Futures in the Northern Territory: Implementation Approach for Community Night Patrols. Available at www.dss.gov.au/sites/default/files/.../community_night_patrols.docx

Australian Government/Closing the Gap (2014) Prime Minister's 2013 Closing the Gap Report. Canberra: Australian Government.

Baldry E and Cunneen C (2014) Imprisoned Indigenous Women and the Shadow of Colonial Patriarchy, Australian and New Zealand Journal of Criminology (forthcoming print). Available at

http://anj.sagepub.com/content/early/2014/03/17/0004865813503351.abstract

Barcham, M (2010) Indigenous Community Policing: Building Strength from Within, in J. Putt (Ed.) Community Policing in Australia: 49-53, Research and Public Policy Series No 111. Canberra: Australian Institute of Criminology.

Bayley D and Shearing C (1996) The Future of Policing, Law and Society Review, 30 (3): 585-606.

Beacroft L, Richards K, Andrevski H and Rosevear L (2011) Community Night Patrols in the Northern Territory: Toward an Improved Performance and Reporting Framework, Technical and Background Paper Series No. 47. Canberra: Australian Institute of Criminology.

Blagg H (2008a) Crime, Aboriginality and the Decolonisation of Justice, Hawkins Press: Sydney.

Blagg H (2008b) Night Patrols: Where Are We Headed? Key Note Address to the Inaugural Northern Territory Night Patrol Service (NPS) Conference, 'Driving Community Safety', 5-7 November, Darwin.

Blagg H (2006) Models of Best Practice: Aboriginal Community Patrols in Western Australia. Nedlands, WA: Crime Research Centre, University of Western Australia. 
African Journal of Criminology and Justice Studies: AJCJS, Vol.8, Special Issue 1: Indigenous Perspectives and Counter Colonial Criminology November 2014

Prepared for the Office of Crime Prevention Unit Perth WA.

http://www.crimeprevention.wa.gov.au/uploads/file/aboriginal community patrol s in wa.pdf

Blagg H (2012) Re-Imagining Youth Justice: Cultural Contestation in the Kimberley Region of Australia since the 1991 Royal Commission into Aboriginal Deaths in Custody, Theoretical Criminology, 16(4): 481.

Blagg H and Valuri G (2001) Profiling Night Patrol Services in Australia, National Crime Prevention and ATSIC Report. Canberra: Attorney Generals Department.

Blagg H and Valuri G (2003) Evaluation of Community Patrols in Western Australia. Perth: Department of Indigenous Affairs.

Blagg H and Valuri G (2004) Aboriginal Community Patrols in Australia: Self-Policing, Self Determination and Security, Policing and Society, 14(4) 313.

Blanchard L and Lui, L (2001) Citizenship and Social Justice: Learning from Aboriginal Night Patrols in NSW, Indigenous Law Bulletin, 5(5): 18.

Charles Darwin University, Social Partnerships in Learning Consortium (2009) Towards An Investment Framework to Reduce Family Violence in the Northern Territory, Evaluation report, volume I. Darwin: Northern Territory Department of Health and Families..

Commonwealth of Australia (2009) Official Committee Hansard, Senate Select Committee on Regional and Remote Indigenous Communities, 1 May, Canberra.

Cohen, S (2007) Against Criminology. New Brunswick: Transaction Books.

Comaroff J and Comaroff JL (2014) Theory from the South: Or, How Euro-America is Evolving Toward Africa. Stellenbosch: SUN MeDIA.

Connell R (2007) Southern Theory: The Global Dynamics of Knowledge in Social Science, Allen and Unwin: London.

Cunneen C (2001) Conflict, Politics and Crime: Aboriginal Communities and Police. Sydney: Allen and Unwin: Sydney.

Cunneen C (2011) Indigeneity, Sovereignty and the Law: Challenging the Process of Criminalisation, South Atlantic Quarterly 2: 110.

Curtis D (1993) Julalikari Council's Community Night Patrol, paper presented to the Aboriginal Justice Issues Conference, 23-25 June, Cairns, in S. McKillop (Ed.) Conference Proceedings: 73-78: Canberra: Australian Institute of Criminology.

de Sousa Santos B (Ed.) (2008) Another Knowledge Is Possible: Beyond Northern Epistemologies. London: Verso.

Escobar A (2011) Encountering Development: The Making and Unmaking of the Third World. Princeton: Princeton University Press.

FaHCSIA (Department of Families, Housing, Community Services and Indigenous Affairs) (2009) Closing the Gap in the Northern Territory: Monitoring Report July December 2009 Part Two, Canberra: Commonwealth of Australia. Available at http://www.fahcsia.gov.au/our-responsibilities/indigenous-

australians/publications-articles/closing-the-gap-in-the-northern-territorymonitoring-report-july-to-december-2009 (accessed 16 September 2013).

Fanon F (2004) The Wretched of the Earth. New York: Grove Press. 


\section{Night Patrols, Indigenous Women, and Place Based Sovereignty: Blagg and Anthony}

Finnane M (1994) Police and Government: Histories of Policing in Australia. Melbourne: Oxford University Press.

Gaykamangu JG (2012) Ngarra Law: Aboriginal Customary Law from Arnhem Land 2 Northern Territory Law Journal, 2(4): 236-248.

Gilroy P (2011) Shameful History: The Social Life of Races and the Postcolonial Archive, Moving Worlds: A Journal of Transcultural Writings, Postcolonial Europe, 11 (2): 19-34.

Hall S (1981) The Whites of their Eyes, in G. Bridges and R. Brunt (Eds.) Silver Linings. Lawrence and Wishart: London: 28-52.

Hook D (2011) A Critical Psychology of the Postcolonial: Biko, Fanon, Racism and Psychoanalysis. London and New York: Routledge.

Higgins D and Associates (1997) Best Practice for Aboriginal Community Night Patrols and Warden Schemes: A Report to the Office of Aboriginal Development. Darwin: Northern Territory Office of Aboriginal Development.

Kelley R (2000) "Slangin' Rocks...Palestinian Style”: Dispatches from the occupied zones of North America, in J. Nelson (Ed.) Police Brutality: An anthology: 21-59. New York and London. W.W. Norton and Company.

Langton M (1991)Too Much Sorry Business, in E. Johnson (Ed.) Royal Commission into Aboriginal Deaths in Custody National Report, Vol. 5: 275-513. Canberra: Attorney Generals Department.

Lee, N (2008) Yuendumu night patrol, Australian Broadcasting Corporation Radio Darwin, $18^{\text {th }}$ March. Available at http://www.abc.net.au/local/stories/2008/03/18/2193307.htm

Loy D (2010) Bush Law, Message Stick Transcript, Australian Broadcasting Corporation, 28 March.

Lloyd, J and Rogers, N (1993) Crossing the last frontier: Problems facing Aboriginal women victims of rape in Central Australia, in P. Easteal (Ed.) Without Consent: Confronting Adult Sexual Violence: Proceedings of a Conference: 149-164. Report No. 20. Canberra: Australian Institute of Criminology.

Marx K (1985) Capital, Volume 1: A Critique of Political Economy. London: George, Allan and Unwin.

Memmott P and Fantin S (2001) 'The Long Grassers': A Strategic Report on Indigenous 'Itinerants' in the Darwin and Palmerston Area (Three volumes) prepared for Territory Housing, Territory Health Services and ATSIC,AERC, University of Queensland. St Lucia (Qld): Paul Memmott and Associates.

Memmott P, Stacy R, Chambers C and Keys C (2001) Violence in Indigenous Communities. Canberra: Attorney-General's Department.

Mignolo W (2011) The Darker Side of Western Modernity: Global Futures, Decolonial Options. Durham (NC): Duke University Press.

Moreton-Robinson A (2007) Writing off Indigenous Sovereignty: The Discourse of Security and Patriarchal White Sovereignty, in A Moreton Robinson (Ed.) Sovereign Subjects: Indigenous Sovereignty Matters. Crows Nest, NSW: Allen and Unwin: 86102.

Mosey A (1994) Central Australian Night Patrols: A Review. Alice Springs: Drug and Alcohol Services Association. 
African Journal of Criminology and Justice Studies: AJCJS, Vol.8, Special Issue 1: Indigenous Perspectives and Counter Colonial Criminology November 2014

Northern Territory Department of Correctional Services (2014) Annual Statistics 2012 2013, Darwin: NT Government

http://www.nt.gov.au/justice/policycoord/researchstats/documents/201213\%20NTCS\%20Annual\%20Statistics.pdf

Northern Territory Law Reform Committee (2003) Report of the Committee of Inquiry into Aboriginal Customary Law, Final Report. Darwin: Northern Territory Law Reform Committee.

Pilkington J (2009) Aboriginal Communities and the Police's Taskforce Themis: Case Studies in Remote Aboriginal Community Policing in the Northern Territory. Darwin: North Australian Aboriginal Justice Agency and Central Australian Legal Aid Service.

Putt $J$ and FaHCSIA (Department of Families, Housing, Community Services and Indigenous Affairs) (2011) Research into Community Safety, Wellbeing and Service Provision. Northern Territory Emergency Response: Evaluation Report. Canberra: FaHCSIA.

Radcliffe S (1999) Reimagining the Nation: Community, Difference, and National Identities Among Indigenous and Mestizo Provincials in Ecuador, Environment and Planning, 31: 37-57.

Reiner R (2000) The Politics of the Police (3rd ed.). Oxford: Oxford University Press.

Ryan P (2001) Lajamanu Night Patrol Service. Darwin: Office of Aboriginal Development.

Ryan P (2005) The Evolving Role and Functions of Remote Area Community Patrols in Dispute Resolution: A Discussion Paper. Darwin: Department of Justice.

Ryan P and Antoun J (2001) Law and Justice Plans: An Overview. Darwin: Office of Aboriginal Development.

Said E (1994) Culture and Imperialism. London: Vintage

Said E (2003) Orientalism. London: Vintage.

Shearing C and Stenning P (1997) Private Policing. Sage: New York.

Simon J (2007) Governing Through Crime: How the War on Crime Transformed American Democracy and Created a Culture of Fear. New York: Oxford University Press.

Smith L (1999) Decolonizing Methodologies: Research and Indigenous Peoples. New York and London: Zed Books.

Spivak GC (1996) The Spivak Reader: Selected Works of Gayatri Chakravorty Spivak. Landry D and Maclaen G (eds). London: Routledge.

Stojanovski A (2010) Dog Ear Café: how the Mt. Theo Program beat the curse of petrol sniffing, Melbourne: Hybrid Publisher

Tangentyere Council Patrollers \& Elek C (2007) 'Relhe marre tnyeneme: community patrols in Alice Springs: keeping people safe' 6(28) Indigenous Law Bulletin 24.

Turner-Walker J (2011) Clash of the Paradigms: Night Patrols in Remote Central Australia, Masters of Criminal Justice thesis, University of Western Australia, Perth.

Walker J and Forrester S (2002) Tangentyere Remote Area Night Patrol, paper presented to the Crime Prevention Conference, Australian Institute of Criminology and the Commonwealth Attorney-General's Department, Sydney, 12-13 September. 


\section{Night Patrols, Indigenous Women, and Place Based Sovereignty: Blagg and Anthony}

Wild R and Anderson P (2007) Ampe Akelyernemane Meke Mekarle: 'Little Children are Sacred', Report of the Northern Territory Board of Inquiry into the Protection of Aboriginal Children from Sexual Abuse. Darwin: Northern Territory Government.

Willis M (2010) Community Safety in Australian Indigenous Communities: Service Providers' Perceptions, Research and Public Policy Series No 110. Canberra: Australian Institute of Criminology.

Zedner L (2006) Policing Before and After the Police: The Historical Antecedents of Contemporary Crime Control, British Journal of Criminology, 46(1): 78-9

\section{Endnotes}

i In the Northern Territory a moiety system divides communities into two groups: 'sun side' and 'shade side'. Most communities also use a section or subsection system with four to eight 'skin names'. An individual gains a 'skin name' upon birth based on the skin names of his or her parents, to indicate the section/subsection that he/she belongs to. See http://www.clc.org.au/articles/info/aboriginal-kinship 